\title{
Effects of a perennial ryegrass diet or total mixed ration diet offered to spring-calving Holstein-Friesian dairy cows on methane emissions, dry matter intake, and milk production
}

\author{
B. F. O’Neill, ${ }^{\star} \dagger$ M. H. Deighton, ${ }^{\star}$ B. M. O’Loughlin, ${ }^{*}$ F. J. Mulligan,† T. M. Boland,† M. O’Donovan, ${ }^{\star}$ \\ and E. Lewis*1 \\ *Grassland Science Research Department, Animal and Grassland Research and Innovation Centre, Teagasc, Moorepark, \\ Fermoy, Co. Cork, Ireland \\ †School of Agriculture, Food Science and Veterinary Medicine, University College Dublin, Belfield, Dublin 4, Ireland
}

\begin{abstract}
The objective of the present study was to compare the enteric methane $\left(\mathrm{CH}_{4}\right)$ emissions and milk production of spring-calving Holstein-Friesian cows offered either a grazed perennial ryegrass diet or a total mixed ration (TMR) diet for $10 \mathrm{wk}$ in early lactation. Fortyeight spring-calving Holstein-Friesian dairy cows were randomly assigned to 1 of 2 nutritional treatments for $10 \mathrm{wk}$ : 1) grass or 2) TMR. The grass group received an allocation of $17 \mathrm{~kg}$ of dry matter (DM) of grass per cow per day with a pre-grazing herbage mass of 1,492 $\mathrm{kg}$ of DM/ha. The TMR offered per cow per day was composed of maize silage $(7.5 \mathrm{~kg}$ of DM), concentrate blend $(8.6 \mathrm{~kg}$ of $\mathrm{DM})$, grass silage $(3.5 \mathrm{~kg}$ of $\mathrm{DM})$, molasses $(0.7 \mathrm{~kg}$ of $\mathrm{DM})$, and straw $(0.5 \mathrm{~kg}$ of $\mathrm{DM})$. Daily $\mathrm{CH}_{4}$ emissions were determined via the emissions from ruminants using a calibrated tracer technique for 5 consecutive days during wk 4 and 10 of the study. Simultaneously, herbage dry matter intake (DMI) for the grass group was estimated using the n-alkane technique, whereas DMI for the TMR group was recorded using the Griffith Elder feeding system. Cows offered TMR had higher milk yield (29.5 vs. $21.1 \mathrm{~kg} / \mathrm{d}$ ), solids-corrected milk yield (27.7 vs. $20.1 \mathrm{~kg} / \mathrm{d})$, fat and protein (FP) yield (2.09 vs. $1.54 \mathrm{~kg} / \mathrm{d}$ ), bodyweight change $(0.54 \mathrm{~kg}$ of gain/d vs. $0.37 \mathrm{~kg}$ of loss/d), and body condition score change (0.36 unit gain vs. 0.33 unit loss) than did the grass group over the course of the 10-wk study. Methane emissions were higher for the TMR group than the grass group (397 vs. $251 \mathrm{~g} / \mathrm{cow}$ per day). The TMR group also emitted more $\mathrm{CH}_{4}$ per $\mathrm{kg}$ of FP (200 vs. $174 \mathrm{~g} / \mathrm{kg}$ of FP) than did the grass group. They also emitted more $\mathrm{CH}_{4}$ per $\mathrm{kg}$ of DMI (20.28 vs. $18.06 \mathrm{~g} / \mathrm{kg}$ of DMI) than did the grass group. In this study, spring-calving cows, consuming a high
\end{abstract}

Received April 21, 2010.

Accepted December 22, 2010.

${ }^{1}$ Corresponding author: eva.lewis@teagasc.ie quality perennial ryegrass diet in the spring, produced less enteric $\mathrm{CH}_{4}$ emissions per cow, per unit of intake, and per unit of FP than did cows offered a standard TMR diet.

Key words: grass, total mixed ration, enteric methane, dairy cow

\section{INTRODUCTION}

Methane $\left(\mathrm{CH}_{4}\right)$, carbon dioxide and nitrous oxide dominate agricultural greenhouse gas (GHG) emissions. Globally, agriculture accounts for $52 \%$ of $\mathrm{CH}_{4}$ emissions (Smith et al., 2008). It is estimated that worldwide agriculture produces 205 to 245 million tonnes of $\mathrm{CH}_{4}$ annually and that 80 million tonnes of this are a product of enteric fermentation in ruminants (Moss et al., 2000).

Due to Ireland's large ruminant population (5.9 million cattle; CSO, 2009) relative to human population (4.2 million people; CSO, 2007), agriculture is a large contributor to Ireland's total GHG emissions. In 2007, the production of $\mathrm{CH}_{4}$ gas from enteric fermentation contributed approximately $12.8 \%$ of total GHG emissions in Ireland (EEA, 2009). Ireland has agreed to limit its GHG emissions to $13 \%$ above 1990 levels under the Kyoto protocol (UNFCCC, 1997) during the first commitment period 2008 to 2012 . Ireland is legally bound to meet this emissions decrease target. As a result, the dairy sector must consider methods to decrease the carbon intensity of milk production.

Methane is a natural end product of rumen fermentation. It arises as a result of anaerobic digestion of feed and the removal of hydrogen from the rumen by methanogenic bacteria. Methane emissions are dependant on the quantity of feed consumed and the composition of the diet (Johnson and Johnson, 1995). Although the feed energy lost as $\mathrm{CH}_{4}$ varies from approximately 2 to $12 \%$ of gross energy intake (GEI) (Johnson et al., 1993), manipulation of feeding strategies can have a large effect on $\mathrm{CH}_{4}$ losses from ruminant animals 
Table 1. Chemical composition of the grass offered over the 10 wk of the study and of the grass consumed during P1 (wk 4) and P2 (wk 10) of the study (mean \pm SD)

\begin{tabular}{|c|c|c|c|}
\hline \multirow[b]{2}{*}{ Item } & \multirow{2}{*}{$\begin{array}{l}\text { Grass offered over } \\
10 \text { wk of study }\end{array}$} & \multicolumn{2}{|c|}{ Selected grass ${ }^{1}$} \\
\hline & & $\mathrm{P} 1$ & $\mathrm{P} 2$ \\
\hline $\mathrm{DM}(\%)$ & $18.4 \pm 2.79$ & $19.1 \pm 1.08$ & $18.8 \pm 0.95$ \\
\hline \multicolumn{4}{|l|}{ DM composition } \\
\hline $\mathrm{CP}(\mathrm{g} / \mathrm{kg}$ of $\mathrm{DM})$ & $241 \pm 25.4$ & $242 \pm 12.6$ & $194 \pm 9.3$ \\
\hline $\mathrm{NDF}(\mathrm{g} / \mathrm{kg}$ of $\mathrm{DM})$ & $465 \pm 23.0$ & $388 \pm 30.9$ & $387 \pm 23.3$ \\
\hline $\mathrm{ADF}(\mathrm{g} / \mathrm{kg}$ of $\mathrm{DM})$ & $294 \pm 22.5$ & $238 \pm 18.6$ & $218 \pm 15.6$ \\
\hline $\operatorname{Ash}(\mathrm{g} / \mathrm{kg}$ of $\mathrm{DM})$ & $106 \pm 20.4$ & $74 \pm 3.6$ & $79 \pm 3.9$ \\
\hline OM digestibility $(\mathrm{g} / \mathrm{kg}$ of $\mathrm{DM})$ & $830 \pm 14.9$ & $869 \pm 15.0$ & $866 \pm 2.8$ \\
\hline Gross energy (MJ/kg of DM) & $\mathrm{NA}^{2}$ & $17.69 \pm 0.241$ & $17.41 \pm 0.136$ \\
\hline
\end{tabular}

(Boadi et al., 2004). For example, in grass-based milk production systems the manipulation of pasture species composition is one of the $\mathrm{CH}_{4}$ mitigation strategies being investigated to decrease emissions (Buddle et al., 2010). The addition of supplementary fat to diets was also shown to be an effective means of decreasing $\mathrm{CH} 4$ emissions (Martin et al., 2010).

The dairy herd in Ireland is made up of 1.1 million dairy cows (CSO, 2009). Ninety percent of Irish dairy herds are spring calving (NMA, 2009) and produce milk from grazed grass, with the mean calving date coinciding with the initiation of grass growth in early spring (Dillon et al., 1995). The remaining dairy herds produce liquid or winter milk. Due to the emphasis on, and importance of, grass, Irish pastures are perennial ryegrass dominant. They are highly productive, producing a feed that is of high quality (O'Donovan, 2000). Indeed, grass in Ireland is of high nutritive value in comparison to many other grass-based dairy production systems around the world, such as mainland Europe (perennial ryegrass, timothy, tall fescue; Connolly et al., 2009) and the United States of America (bromegrass, orchardgrass, Kentucky bluegrass; Bargo et al., 2002).

In 2015, milk quota will be abolished (EC, 2009), resulting in land and not quota being the limiting factor to expansion. As a consequence, farmers will increase cow numbers (DAFF, 2010) on the same land base, resulting in increased stocking rate, thus forcing farmers to consider supplementary feeding and alternative feeding systems (e.g., TMR). The increased fat and protein (FP) yield from such a system may offset the higher $\mathrm{CH}_{4}$ emissions expected from the higher DMI in this system. Thus, the objective of this study was to compare the enteric $\mathrm{CH}_{4}$ emissions and milk production of spring-calving Holstein-Friesian dairy cows managed in a grass-based system with those managed in a higher input TMR-based system.

\section{MATERIALS AND METHODS}

The study was conducted at Moorepark Dairy Production Research Centre, Fermoy, Co Cork, Ireland $\left(52^{\circ} 16^{\prime} \mathrm{N}, 8^{\circ} 25^{\prime} \mathrm{W}\right)$. The soil type was a free-draining, acid brown earth with a sandy loam-to-loam texture.

\section{Animals and Experimental Design}

The study commenced in spring 2009 and took place over a 10-wk period from March 23 to May 31. Fortyeight Holstein-Friesian dairy cows were selected from the Moorepark spring-calving dairy herd. Eighteen cows were primiparous, 17 were in their second lactation and the remaining 13 were in their third lactation or greater.

Animals were blocked on the basis of parity, BW, BCS, DIM, and milk yield, and were randomly assigned $(\mathrm{n}=24)$ to 1 of 2 treatments: 1$)$ grass (Table 1$)$ or 2) TMR. The stage of lactation was identical for both treatment groups due to its inclusion as a blocking factor. On average, cows were 64 DIM $(\mathrm{SD}=17)$ during the April measurement period (wk 4; P1) and 104 DIM $(\mathrm{SD}=17)$ during the May measurement period (wk 10; P2).

\section{Treatments and Grazing Management}

During the pre-experimental period, after cows had calved, all cows were offered a mixed diet, which was comprised of a grass allowance and an allowance of TMR. The cows were offered a daily herbage allowance (DHA) of $8 \mathrm{~kg}$ of grass DM/cow per day after the a.m. milking. The DHA was calculated above 4 $\mathrm{cm}$. The TMR allowance of $10 \mathrm{~kg}$ of $\mathrm{DM} / \mathrm{cow}$ per day was offered after the p.m. milking. Cows were kept indoors overnight. During the final pre-experimental week, the DHA of cows allocated to the grass treat- 
Table 2. Chemical composition of the TMR offered over the $10 \mathrm{wk}$ of the study

\begin{tabular}{|c|c|c|c|c|c|c|}
\hline Item & $\begin{array}{l}\text { Maize } \\
\text { silage }\end{array}$ & $\begin{array}{l}\text { Grass } \\
\text { silage }\end{array}$ & Concentrate & $\begin{array}{l}\text { Barley } \\
\text { straw }\end{array}$ & Molasses $^{1}$ & $\begin{array}{c}\text { Total } \\
\text { TMR }^{2}\end{array}$ \\
\hline DM $(\%)$ & 22.7 & 24.6 & 88.5 & 79.3 & 73.7 & 35.8 \\
\hline \multicolumn{7}{|l|}{ DM composition } \\
\hline $\mathrm{NDF}(\mathrm{g} / \mathrm{kg}$ of $\mathrm{DM})$ & 489 & 514 & 188 & 790 & $\mathrm{NA}^{3}$ & 355 \\
\hline Ash $(\mathrm{g} / \mathrm{kg}$ of $\mathrm{DM})$ & 31 & 80 & 49 & 26 & 140 & 52 \\
\hline Starch $(\mathrm{g} / \mathrm{kg}$ of DM $)$ & 179 & NA & 235 & 15 & NA & 159 \\
\hline
\end{tabular}

${ }^{1}$ Values from Sauvant et al. (2004).

${ }^{2}$ Calculated from ingredient content of TMR and ingredient chemical composition.

${ }^{3}$ Not available.

${ }^{4}$ Values from O'Mara (1996).

ment was gradually increased and their TMR allowance decreased. By the beginning of the study, these cows were outdoors grazing full-time and receiving no TMR. Cows allocated to the TMR treatment were offered the TMR with a gradual increase in the concentrate level over the pre-experimental week until d 1 of the study when they were offered the TMR experimental formulation (Table 2) and no grass.

Cows allocated to the grass treatment were offered a DHA of $17 \mathrm{~kg}$ of grass DM $(100 \%$ Lolium perenne L.) and grazed to a post-grazing height of $4 \mathrm{~cm}$. The grazing area for the study consisted of 7.8 ha divided into 15 individual paddocks. Cows were grazed in a rotational system and were allocated fresh grass daily after a.m. milking. Paddocks were strip grazed using temporary electric fences. Cows had access to the previous day's allocation, as cows often grazed paddocks for 2 to $3 \mathrm{~d}$ and no back fences were erected. Swards were not topped or grazed by a nontreatment herd to maintain grass quality during the experiment. Nitrogen was applied after each grazing at a rate of $33 \mathrm{~kg}$ of $\mathrm{N} /$ ha. On a daily basis, before grazing, paddocks were dusted with calcined magnesite (Cal-Mag, Nutribio Ltd., Co. Cork, Ireland) at a rate of $210 \mathrm{~g} /$ cow per day to ensure adequate intake of magnesium to prevent hypomagnesemia.

Cows allocated to the TMR treatment were housed indoors as a single group, with cubicle accommodation, for the duration of the study. The TMR was composed of $(\mathrm{g} / \mathrm{kg}$ of $\mathrm{DM}) 360$ maize silage, 410 concentrate blend, 170 grass silage, 30 molasses, and 30 barley straw. The concentrate blend contained (g/kg of DM) 375 soybean meal, 335 rolled barley, 116 maize gluten meal, 115 citrus pulp, 27 mineral and vitamin pre-mix, 22 vegetable fat, and 10 limestone. The TMR was offered ad libitum with at least $5 \%$ daily feed refusal (as-fed basis). Residual feed was removed daily. New feed was mixed and distributed once every day during a.m. milking using a Keenan Klassik 140 diet feeder (Keenan Ltd., Co. Carlow, Ireland) and was fed via a Griffith Elder feeding system (Griffith Elder Ltd., Bury St. Edmunds, Suffolk, UK). All cows were acclimatized to the use of the feeding system during the pre-experimental period.

\section{Sward and TMR Measurements}

Herbage mass $(>4 \mathrm{~cm})$ was determined twice weekly by cutting 4 strips of grass per paddock $(1.2 \mathrm{~m} \times 10 \mathrm{~m})$ using an Etesia mower (Etesia UK Ltd., Warwick, UK). Ten measurements of sward height were recorded using a rising plate meter (Jenquip, Feilding, New Zealand) before and after each strip was cut. All mown herbage from each strip was weighed and sampled $(0.3 \mathrm{~kg})$. A subsample $(0.1 \mathrm{~kg})$ was dried and used for DM determination at $90^{\circ} \mathrm{C}$ for $16 \mathrm{~h}$ in a drying oven (Carbolite, Derbyshire, UK). The remainder of the sample $(0.2$ $\mathrm{kg}$ ) from each of the 4 strips were pooled and mixed. This sample was then dried at $40^{\circ} \mathrm{C}$ for $48 \mathrm{~h}$ in the drying oven, and was milled to pass through a 1-mm sieve (Cyclotec 1093 Sample Mill, Foss Electric DK, 3400 Hillerød, Denmark) in preparation for chemical analysis.

Pre-grazing sward height was recorded throughout the experimental period by averaging 60 measurements across the 2 diagonals of each paddock using the rising plate meter. Post-grazing sward height was also recorded using the same method.

Samples of each ingredient used in the TMR were taken weekly throughout the study. The DM of these samples was determined by drying at $40^{\circ} \mathrm{C}$ for $24 \mathrm{~h}$ in the drying oven and the composition of the TMR was adjusted weekly as necessary to maintain the correct composition. The dried samples were milled to pass through a 1-mm sieve in preparation for chemical analysis. 


\section{Chemical Analysis}

Samples of the grass offered and grass representative of that grazed (accounting for the previous defoliation height recorded from each treatment) were analyzed by wet chemistry for DM, CP, NDF, ADF, ash, organic matter digestibility (OMD), and gross energy (GE). The samples were analyzed for DM as described previously. The N content was determined using a Leco FP 428 N analyzer (Leco Australia Pty Ltd., Castle Hill, New South Wales, Australia) with a method adapted by Sweeney (1989). Crude protein was determined as N content $\times 6.25$. The NDF and ADF of the samples were analyzed using the Ankom Fiber Analyzer (Ankom Technology Corporation, NY) using the procedure of Van Soest et al. (1991). Amylase and sulfite were used in the process of NDF analysis. The values for ADF and NDF do not include ash. Ash content was determined by placing samples in a muffle furnace for $16 \mathrm{~h}$ at $500^{\circ} \mathrm{C}$. The OMD of the grass was determined using the in vitro neutral detergent cellulase method as described by Morgan et al. (1989; Fibertec Systems, FOSS, Ballymount, Dublin, Ireland). Gross energy was determined from pelletized samples using a bomb calorimeter (Parr Instrument Company, Moline, IL). The maize silage and barley straw samples were analyzed individually for DM, CP, ash, NDF, and GE using the methodologies described above. In addition, starch concentration was analyzed by treating the sample with hot dilute hydrochloric acid. Following clarification and filtration, the optical rotation of the prepared solution was measured using an automatic polarimeter (Optical Activity Ltd., Ramsey, Cambridgeshire, UK). The chemical composition of the grass silage and concentrate was analyzed by near-infrared reflectance spectroscopy (Model 6500, FOSS-NIR System DK, 3400 Hillerød, Denmark). The GE of the grass silage and concentrate was analyzed by wet chemistry as described above.

\section{Animal Measurements}

Milk Yield, Composition, BW, and BCS. The cows were milked twice daily at $0800 \mathrm{~h}$ and $1500 \mathrm{~h}$. Individual milk yields were recorded automatically at each milking (Dairymaster, Causeway, Co. Kerry, Ireland). Milk fat, milk protein, and milk lactose concentrations were determined weekly from an a.m. and a p.m. milk sample taken on successive days and pooled in proportion to milk yield. During the measurement periods P1 and P2, a second a.m. and p.m. sample was taken the day after the routine weekly test. The concentrations of milk constituents were determined using a Milkoscan 203 (Foss Electric DK, 3400 Hillerød, Denmark). Solidscorrected milk yield was calculated using the equation of
Tyrrell and Reid (1965). The FP yield was calculated as the total kilograms of fat plus protein produced per cow per day, by multiplying the concentrations of fat and protein in the milk by the yield of milk. The milk solids yield was calculated as the total $\mathrm{kg}$ of fat plus protein plus lactose produced per cow per day, by multiplying the concentrations of fat and protein and lactose in the milk by the yield of milk.

All cows were weighed weekly. Bodyweight was recorded electronically using portable weighing scales and Winweigh software package (Tru-test Limited, Auckland, New Zealand).

Body condition score was recorded every $2 \mathrm{wk}$, by 1 experienced observer, on a scale from 1 (emaciated) to 5 (extremely obese) with increments of 0.25 (Lowman et al., 1976).

DMI Measurements. Individual DMI for all the cows was measured during the 2 measurement periods $\mathrm{P} 1$ and $\mathrm{P} 2$.

The DMI for the grass-fed group was estimated using the n-alkane technique (Mayes et al., 1986), as modified by Dillon and Stakelum (1989). The grass-fed group were dosed twice daily for 11 consecutive days with a paper bolus (Carl Roth GmbH and Co. KG, Karlsruhe, Germany) containing $500 \mathrm{mg}$ of dotriacontane $\left(\mathrm{C}_{32}\right)$. From the seventh day of dosing onwards, a fecal sample was collected twice daily from each individual cow (a.m. and p.m.). The fecal samples were then bulked by cow (15 g per sample, giving a bulk sample for each cow of $150 \mathrm{~g})$. These bulked samples were dried for $48 \mathrm{~h}$ at $60^{\circ} \mathrm{C}$ in a drying oven, and then milled in preparation for analysis of alkane concentrations. Grass representative of that grazed (accounting for the previous defoliation height recorded from each treatment) from d 6 to 10 of each of the 2 intake measurement periods was collected manually before cows entered the paddock. Two samples of approximately 25 individual grass snips were taken from each paddock with Gardena hand shears (Accu 60, Gardena International GmbH, Ulm, Germany). The samples were stored at $-20^{\circ} \mathrm{C}$ before being freeze-dried and milled before chemical analysis. The n-alkane concentration was determined as described by Dillon (1993). The ratio of herbage $\mathrm{C}_{33}$ (tritriacontane) to dosed $\mathrm{C}_{32}$ was used to estimate intake.

Dry matter intake for the TMR group was also recorded during the 2 measurement periods P1 and P2. At this time the Griffith Elder feeding system recorded the fresh weight of TMR consumed by each animal each day. During the 2 measurement periods, samples of each ingredient used in the TMR were taken daily. The DM of these samples was analyzed. This enabled the weight of the feed consumed (as-fed) to be converted to DMI.

Enteric $\mathrm{CH}_{4}$ Measurements. The daily $\mathrm{CH}_{4}$ emissions of each cow were determined via the emissions 
from ruminants using a calibrated tracer technique. This study used sulfur hexafluoride $\left(\mathbf{S F}_{\mathbf{6}}\right)$ tracer gas as described by Johnson et al. (2007), with equipment modifications for free-ranging dairy cattle.

Tracer gas permeation tubes were filled with approximately $2.5 \mathrm{~g}$ of $\mathrm{SF}_{6}$ during January 2009. A linear rate of $\mathrm{SF}_{6}$ emission was confirmed via gravimetric weighing to produce an 8-point regression curve $\left(\mathrm{R}^{2}\right.$ $>0.99$ ) during incubation in $39^{\circ} \mathrm{C}$ air at the trial site. Tubes were blocked by emission rate $(6.88 \mathrm{mg} / \mathrm{d}, \mathrm{SD}$ $=0.60)$ and randomly allocated to both experimental treatment and cow within treatment. The tubes were dosed orally $10 \mathrm{~d}$ before the commencement of sample collection for P1.

To ensure freedom of movement and reliability of sampling during grazing, indoor housing, and milking, the gas collection canisters were fitted on the back of each cow using a foam-filled canvas saddle. Each saddle was mounted between the shoulders and hipbones and held in place with 2 Velcro strips affixed to the cow either side of the midline. The saddle was secured using 2 elasticized girth straps crossing under the cow's brisket and an adjustable strap extending from the rear of the saddle to a padded strap around the base of the cows tail. Expired and eructated gases along with ambient air were drawn into the evacuated collection canister via a halter-mounted tube looped above the cows mouth and nostrils. The rate of sample collection was restricted to $0.5 \mathrm{~mL} / \mathrm{min}$ via passage through a $50 \mathrm{~mm}$ length of stainless steel capillary tubing with internal diameter of $12.7 \mu \mathrm{m}$ (Valco Instruments Co. Inc., Houston, TX) crimped at several points and calibrated using a digital flow meter (Cole-Parmer Instrument Co., Vernon Hills, IL). Each pre-calibrated restriction tube was fixed into a proprietary aluminum brace to prevent loss of calibration during the collection period. Gases were sampled for 5 consecutive 24-h periods using an initial canister vacuum 900 mbar below atmospheric pressure. A 120-h continuous sampling period was achieved using the rotation of 3 canisters/cow. Sample concentrations of $\mathrm{SF}_{6}$ and $\mathrm{CH}_{4}$ were determined via gas chromatography as described by Johnson et al. (2007) using a Varian 3800 gas chromatograph (Varian Inc., Palo Alto, CA).

A power analysis calculation was performed using data from a previously-published large-scale study utilizing the $\mathrm{SF}_{6}$ technique, which reported that the coefficient of variation in daily $\mathrm{CH}_{4}$ emission of pasture-grazed cows ranged between 0.11 and 0.136 (McNaughton et al., 2005). The power analysis assumed $\alpha=0.05, \sigma$ $=36, \mu 1=300 \mathrm{~g}$ of $\mathrm{CH}_{4} /$ cow per day, $\mu 2=330 \mathrm{~g}$ of $\mathrm{CH}_{4} /$ cow per day (i.e., treatment effect $10 \%$ ) and $\mathrm{n}=$ 24. This calculation yielded an experimental power of 0.82 .

\section{Statistical Analysis}

All statistical analyses were carried out using SAS 9.1.3 (SAS Institute, 2005). Average milk production, milk composition, BW, and BCS over the course of the 10 -wk study were analyzed by ANOVA using covariate analysis and the following model:

$$
Y_{i j}=\mu+P_{i}+T_{j}+P_{i} \times T_{j}+b_{1} X_{i j}+b_{2} \mathrm{DIM}_{i j}+e_{i j},
$$

where $Y_{i j}=$ the response of animal in parity $i$ offered treatment $j, \mu=$ mean, $P_{i}=$ parity $(i=1$ to 4$), T_{j}$ $=$ treatment $(j=1$ to 2$), P_{i} \times T_{j}=$ interaction of $P$ $\times T, b_{1} X_{i j}=$ the respective pre-experimental variable, $b_{2} \mathrm{DIM}_{i j}=$ the days in milk at the start of the experiment, and $e_{i j}=$ residual error term.

The data for P1 and P2 were analyzed using the MIXED procedure of SAS. The linear model included diet, measurement period, block, and diet $\times$ measurement period as fixed effects, with cow as a random repeated effect. As no diet $\times$ measurement period interactions were evident, the interaction was removed from the model and effects of diet and measurement period alone are presented.

The daily $\mathrm{CH}_{4}$ emission of individual cows was measured for 5 consecutive 24-h periods and averaged to yield a single daily value for each cow representative of the entire sampling period. Collection of the 480 gas samples was $96 \%$ successful. The remainder was not collected because of blockages in the tubing or dismounting of canisters and saddles during the 24-h collection periods. All of the data included in the statistical analysis represent mean values calculated from a minimum of 3 consecutive measurements. Eighty-five per cent of the $\mathrm{CH}_{4}$ data were derived from 5 individual measurements as intended.

\section{RESULTS}

\section{Climatic Conditions}

Rainfall values for both April (106.7 mm) and May $(88.6 \mathrm{~mm})$ were $41.6 \mathrm{~mm}$ and $12.1 \mathrm{~mm}$ respectively above the previous 10-yr average. April had a mean temperature of $8.9^{\circ} \mathrm{C}$, which was equal to the 10 -yr average. May had a mean temperature of $11^{\circ} \mathrm{C}$, with the 10 -yr average being $11.6^{\circ} \mathrm{C}$. The total hours of sunshine were $136 \mathrm{~h}$ for April, which was below the 10-yr average of $158 \mathrm{~h}$, and $174 \mathrm{~h}$ for May, which was slightly below the 10-yr average of $179 \mathrm{~h}$.

\section{Grass Measurements and Feed Chemical Analysis}

Pre-grazing herbage mass of the grass grazed was $1,492 \mathrm{~kg}$ of $\mathrm{DM} / \mathrm{ha}(\mathrm{SD}=332)$. The average pre-graz- 
Table 3. The effect of a perennial ryegrass or TMR diet offered in early lactation in spring on enteric methane emissions, DMI, and milk production during P1 (measurement period 1, wk 4) and P2 (measurement period 2, wk 10) of the study

\begin{tabular}{|c|c|c|c|c|c|c|c|c|}
\hline Item & \multicolumn{4}{|c|}{ Diet } & \multicolumn{4}{|c|}{ Measurement period } \\
\hline $\mathrm{GEI}^{2}(\mathrm{MJ} / \mathrm{cow}$ per day) & 250 & 343 & 6.0 & 0.001 & 281 & 313 & 5.9 & 0.001 \\
\hline Milk yield ( $\mathrm{kg} / \mathrm{cow}$ per day) & 19.58 & 26.96 & 0.574 & 0.001 & 24.60 & 21.91 & 0.478 & 0.001 \\
\hline $\mathrm{SCM}$ yield ( $\mathrm{kg} /$ cow per day) & 18.98 & 25.84 & 0.524 & 0.001 & 24.12 & 20.70 & 0.467 & 0.001 \\
\hline Milk lactose $(\mathrm{g} / \mathrm{kg})$ & 47.3 & 48.3 & 0.19 & 0.001 & 48.2 & 47.3 & 0.23 & 0.001 \\
\hline Fat and protein yield ( $\mathrm{kg} / \mathrm{cow}$ per day) & 1.47 & 1.97 & 0.040 & 0.001 & 1.84 & 1.60 & 0.036 & 0.001 \\
\hline Milk solids yield ${ }^{3}(\mathrm{~kg} / \mathrm{cow}$ per day $)$ & 2.37 & 3.27 & 0.066 & 0.001 & 3.00 & 2.64 & 0.056 & 0.001 \\
\hline $\mathrm{CH}_{4}$ emissions ( $\mathrm{g} / \mathrm{kg}$ of $\left.\mathrm{DMI}\right)$ & 18.06 & 20.28 & 0.565 & 0.011 & 19.76 & 18.58 & 0.527 & 0.037 \\
\hline $\mathrm{CH}_{4}$ emissions $(\mathrm{g} / \mathrm{kg}$ of fat and protein yield) & 174 & 200 & 4.8 & 0.001 & 172 & 203 & 4.1 & 0.001 \\
\hline GEI lost as $\mathrm{CH}_{4}(\%)$ & 5.74 & 6.47 & 0.179 & 0.008 & 6.28 & 5.93 & 0.166 & 0.05 \\
\hline
\end{tabular}

${ }^{1}$ Reported as least squares means.

${ }^{2}$ Gross energy intake.

${ }^{3}$ Fat yield + protein yield + lactose yield.

ing and post-grazing sward heights for the study period were $9.4 \mathrm{~cm}(\mathrm{SD}=1.26)$ and $4.1 \mathrm{~cm}(\mathrm{SD}=0.51)$. The chemical composition of the offered grass and selected herbage is presented in Table 1 . The grass was highly digestible with a high mean OMD and a high mean CP concentration. The chemical composition of the TMR offered is presented in Table 2.

\section{DMI}

Dry matter intake was higher $(P<0.001)$ for the TMR group than for the grass-fed group (Table 3 ).

\section{Milk Production and Milk Composition}

Over the course of the 10 -wk study, milk production was $40 \%$ higher $(P<0.001)$ by cows offered the TMR diet than by cows offered the grass diet (Table 4). Solids-corrected milk yield was also higher $(P<$
0.001) for cows offered the TMR diet. The TMR group produced milk with higher lactose concentration $(P<$ 0.01 ) and grass-fed cows produced milk with a higher $(P<0.05)$ milk protein concentration, but milk fat concentration was similar $(P>0.05)$ between treatments. Cows offered TMR produced higher FP yield/ cow per day $(P<0.001)$ and, similarly, produced higher milk solids yield/cow per day $(P<0.001)$ than did the grass-fed cows. The production and composition of milk during the 2 measurement periods is presented in Table 3 and the differences between treatments mirror those observed over the course of the 10-wk study, as presented in Table 4.

\section{$B W$ and BCS}

Significant differences were found between grass- and TMR-fed cows with regard to mean BCS $(P<0.001)$, mean BW $(P<0.001)$, BCS change $(P<0.05)$, and

Table 4. The effect of a perennial ryegrass or TMR diet offered in early lactation in spring on milk production and cow condition during the 10 -wk study

\begin{tabular}{|c|c|c|c|c|}
\hline Item & Grass $^{1}$ & $\mathrm{TMR}^{1}$ & SEM & $P$-value \\
\hline Milk yield (kg/cow per day) & 21.1 & 29.5 & 0.35 & 0.001 \\
\hline SCM yield (kg/cow per day) & 20.1 & 27.7 & 0.35 & 0.001 \\
\hline Milk fat $(\mathrm{g} / \mathrm{kg})$ & 41.5 & 40.2 & 0.66 & 0.49 \\
\hline Milk protein (g/kg) & 32.5 & 31.1 & 0.25 & 0.049 \\
\hline Milk lactose $(\mathrm{g} / \mathrm{kg})$ & 47.5 & 48.7 & 0.13 & 0.003 \\
\hline Fat and protein yield (kg/cow per day) & 1.54 & 2.09 & 0.028 & 0.001 \\
\hline Milk solids yield ${ }^{2}(\mathrm{~kg} /$ cow per day) & 2.54 & 3.52 & 0.041 & 0.001 \\
\hline $\mathrm{BCS}$ & 2.91 & 3.22 & 0.023 & 0.001 \\
\hline BW (kg) & 478 & 546 & 2.0 & 0.001 \\
\hline BCS change over $10 \mathrm{wk}$ & -0.33 & 0.36 & 0.105 & 0.02 \\
\hline BW change (kg/d) & -0.37 & 0.54 & 0.057 & 0.001 \\
\hline
\end{tabular}

${ }^{1}$ Reported as least squares means.

${ }^{2}$ Milk solids yield $=$ Fat yield + protein yield + lactose yield . 
BW change $(P<0.001)$ over the 10 -wk study (Table 4$)$. Cows on the TMR treatment had a greater mean BCS and higher mean BW. In addition, the grass-fed group lost BW and BCS, but the TMR-fed group gained BW and BCS.

\section{Enteric $\mathrm{CH}_{4}$ Emissions}

Methane emissions per cow were lower $(P<0.001)$ in the grass-fed group than in the TMR group (Table 3 ). The grass-fed group also emitted less $(P<0.001) \mathrm{CH}_{4}$ per $\mathrm{kg}$ of $\mathrm{FP}$ and less $(P<0.05) \mathrm{CH}_{4}$ per $\mathrm{kg}$ of DMI than did the TMR-fed group. The grass-fed group lost a lower $(P<0.01)$ percentage of GEI as $\mathrm{CH}_{4}$ energy compared with cows consuming the TMR diet.

\section{Period Effects on Performance}

As expected, an effect of period on performance was noted (Table 3$)$. Dry matter intake was higher $(P<$ $0.001)$ in $\mathrm{P} 2$ than in P1. Milk yield was lower $(P<$ $0.001)$ in $\mathrm{P} 2$ than in P1. Milk fat concentration was also lower $(P<0.01)$ in $\mathrm{P} 2$ compared with $\mathrm{P} 1$. As a result of these differences, FP yield was lower $(P<0.001)$ in $\mathrm{P} 2$ than in $\mathrm{P} 1$. Milk protein concentration increased $(P$ $<0.001)$ from P1 to P2.

The daily $\mathrm{CH}_{4}$ emissions per cow $(P<0.05)$ and per $\mathrm{kg}$ of $\mathrm{FP}(P<0.001)$ were higher in $\mathrm{P} 2$ than in $\mathrm{P} 1$. The $\mathrm{CH}_{4}$ emissions per $\mathrm{kg}$ of DMI and the percentage of GEI lost as $\mathrm{CH}_{4}$ were lower $(P<0.05)$ in $\mathrm{P} 2$ than in $\mathrm{P} 1$.

\section{DISCUSSION}

Matching nutrient supply to animal demand in an environmentally and economically efficient manner is one of the key drivers in intensive ruminant production systems. The objective of the current study was to compare a grass-based system of milk production in spring to a TMR-based feeding system with regard to enteric $\mathrm{CH}_{4}$ emissions, DMI, and milk production. Very few direct comparisons exist in the literature of $\mathrm{CH}_{4}$ emissions from dairy cows grazing grass with those in confinement offered TMR.

The pre-grazing herbage mass and the post-grazing sward heights are within the parameters set down by O'Donovan (2000) for well-managed grass. The chemical composition of grass offered and selected was of high quality. These grass composition parameters are comparable with those reported in other Irish grazing studies for high quality grass during the spring period (Kennedy et al., 2008, Curran et al., 2010). This type of grass is often superior in quality to grass offered in other studies internationally (e.g., Bargo et al., 2002 and Fontaneli et al., 2005).

The TMR offered to the cows was also of high quality and was comparable in chemical composition to TMR fed in other studies (Kolver and Muller, 1998; Grainger et al., 2009), apart from the DM content. The DM content of the TMR in the current study was lower than that of TMR offered in some other studies (Kolver and Muller, 1998; Tucker et al., 2001; Bargo et al., 2002). This was mainly due to the low DM of the maize and grass silages used. The maize silage is typical of maize produced in Ireland during a poor growing season with low DM content, poorly developed cobs, and low starch content (Fitzgerald and Murphy, 1999).

\section{Production Performance}

Dry matter intake is a major driver of $\mathrm{CH}_{4}$ production (Hegarty et al., 2007) and is a limiting factor to milk production in early lactation (Kertz et al., 1991). The DMI in the current study was lower for both treatments than for similar studies, which compared TMR with grass (Robertson and Waghorn, 2002; Patton et al., 2008). This could be due to the high proportion of primiparous animals (0.375) used in the current study, as DMI is considerably higher in multiparous cows compared with primiparous cows (Ingvartsen and Andersen, 2000). It could also be due to differences in the genetic merit of the animals involved in the different studies. In addition, the study of Robertson and Waghorn (2002) used only 5 animals per treatment, which makes interpreting their results more difficult. The lower DMI for grass-fed cows is in accordance with other studies comparing grass and TMR (Robertson and Waghorn, 2002; Patton et al., 2008). Kolver and Muller (1998) speculated that the lower intake of the grass group was due to 3 key factors that influenced the ingestive behavior of cows offered grass: DM per bite, bite rate, and grazing time.

The higher milk yield and SCM yield supported by the TMR diet in the current study are in agreement with previous studies (Kolver et al., 2000; White et al., 2002). Kolver and Muller (1998) concluded that the lower milk production of high-producing dairy cows grazing high quality grass compared with a TMR was due to lower DMI. Milk yield in the current study was lower for both treatments compared with that in similar experiments previously undertaken (Kolver and Muller, 1998; Bargo et al., 2002). This is likely due to the lower DMI of the animals in the current experiment compared with that in other studies.

The higher protein concentration and similar fat concentration of milk from grass-fed cows compared with 
those of TMR-fed cows correspond with the findings of previous studies (Patton et al., 2008). In terms of milk protein concentration, rapidly fermentable dietary carbohydrate has been associated with an increase in milk protein concentration (Jenkins and McGuire, 2006). Thus, the higher milk protein concentration of the milk from the grass-fed group may have been caused by the higher digestibility of the grass diet compared with the TMR diet. Indeed Murphy et al. (2008) found a significant effect of higher midseason grass quality on increasing milk protein concentration. Both diets in the current study were well balanced for fiber levels (NRC, 2001) and this likely accounted for the similarity in milk fat levels between treatments. In addition, the milk fat concentration of cows in early lactation is less responsive to diet than later in lactation (Allen, 1997). Cows in the current study were early in lactation and, as a result, it is possible that the effect of diet did not influence milk fat concentration as much as it may later in lactation. Overall, FP yield by the TMR group was higher than by the grass-fed group. This was driven by the difference in milk yield between the 2 treatments. Milk lactose concentration is positively associated with milk yield (Linzell and Peaker, 1971) and thus, as expected, the milk lactose concentration of the TMR group was higher than that of the grass-fed group.

Body condition score is important in the evaluation of nutritional status and performance of the dairy cow (Tucker et al., 2001). The difference in BCS and BW between treatments corresponds with the findings of other studies (Kolver and Muller, 1998; Washburn et al., 2002). For example, Washburn et al. (2002) reported that cows offered pasture were between 0.3 and 0.6 units lower in BCS than cows offered a TMR over a full lactation. The loss of BW by the grass-fed group on the current study was similar to that displayed by cows offered different DHA with no concentrate in the study of Kennedy et al. (2007). The lower BW and BCS and greater losses in BW and BCS by cows in the grass-fed group can be attributed to the differences in DMI between the 2 groups of cows. Cows grazing grass are limited in the quantity of fresh forage that they can consume (Holden et al., 1994). This was true in the current study where the grass-fed group had lower DMI.

As expected, an effect of period on many of the production performance variables measured was found. This was due to the later stage of lactation of all cows in P2, which accounted for the increased DMI and decreased milk yield and FP yield. The later stage of lactation along with the growth stage of the grass in May (P2) as compared with April (P1) gave rise to the lower fat and higher protein concentrations (CSO, 2010) in P2 compared with P1.

\section{Methane Production}

Methane emissions per cow per day in the current study were generally lower than in the study of Robertson and Waghorn (2002), where New Zealand- and overseas-genotype cows were offered TMR or pasture. The higher $\mathrm{CH}_{4}$ emissions in that study (Robertson and Waghorn, 2002) may be explained by the higher DMI achieved, as DMI is the main driver of enteric $\mathrm{CH}_{4}$ emissions (Hegarty et al., 2007). However, in the study of Robertson and Waghorn (2002), $\mathrm{CH}_{4}$ emissions and DMI were measured on only 5 cows per treatment at each measurement period, which may pose limitations in the interpretation of the results. Increasing DMI increases $\mathrm{CH}_{4}$ production, as a greater DMI provides a greater intake of fermentable substrate, including both structural and nonstructural carbohydrates (Moe and Tyrrell, 1980). Both the current study and Robertson and Waghorn (2002) found that in early lactation, pasture-fed cows produced less $\mathrm{CH}_{4}$ emissions per day than cows offered TMR. The higher DMI exhibited by the TMR-fed cows in both studies is likely to have caused the increased $\mathrm{CH}_{4}$ emissions by these cows, via the mechanisms discussed above.

The expression of $\mathrm{CH}_{4}$ production on a per unit of feed intake basis allows $\mathrm{CH}_{4}$ production to be compared with regard to the consumed feed composition while removing the large DMI effect. The grass-fed group produced less $\mathrm{CH}_{4}$ emissions per $\mathrm{kg}$ of DMI, which is in agreement with Robertson and Waghorn (2002), who found that at 60 DIM, New Zealand cows offered pasture produced $18.0 \mathrm{~g}$ of $\mathrm{CH}_{4} / \mathrm{kg} \mathrm{DMI}$, whereas cows offered TMR produced $20.3 \mathrm{~g}$ of $\mathrm{CH}_{4} / \mathrm{kg}$ of DMI (results which are very similar to the current study). The differences between treatments in the current study can be explained by the feed composition. The grass-fed group was offered highly digestible grass. Indeed the OMD of the grass during the study was higher than that of the TMR (830 vs. $768 \mathrm{~g} / \mathrm{kg}$ of DM). It has been shown that increased digestibility of feeds results in less $\mathrm{CH}_{4}$ being emitted per $\mathrm{kg}$ of DMI when feeding is considerably greater than maintenance (Blaxter and Clapperton, 1965), as it was in the current study. The higher digestibility of the grass consumed compared with the TMR is due to the higher CP levels in the grass in association with the highly digestible nature of the fiber fractions present in grass generally (Van Vuuren et al.,1992; Kolver and Muller, 1998; Tas et al., 2005). Highly digestible diets give rise to less $\mathrm{CH}_{4}$ production per $\mathrm{kg}$ of DMI for several different reasons. One of these is that highly digestible feeds can give rise to low ruminal $\mathrm{pH}$ due to their rapid and extensive fermentation in the rumen (Krause and Oetzel, 2006; Curran et al., 
2010). Low ruminal $\mathrm{pH}$ inhibits the growth of protozoa and methanogens, thus decreasing $\mathrm{CH}_{4}$ production (Van Kessel and Russell, 1996; Russell, 1998). Low ruminal $\mathrm{pH}$ also decreases fiber digestibility, leading to decreased $\mathrm{CH}_{4}$ production. It has been shown that grass diets can give rise to low ruminal $\mathrm{pH}$ (O'Grady et al., 2008; Lewis et al., 2010). Furthermore, rumen $\mathrm{pH}$ on the TMR treatment may have been buffered by a higher saliva production, associated with greater DMI (Pinares-Patiño et al., 2007). In addition, the CP concentration of the grass diet was greater than that of the TMR diet, whereas the predicted NSC concentration of the grass diet was less than that of the TMR diet. Demeyer and Van Nevel (1979) and Cone and van Gelder (1999) showed that protein produces less $\mathrm{CH}_{4}$ than carbohydrate. The combination of higher protein and lower NSC in the grass would be expected to result in decreased $\mathrm{CH}_{4}$ production, which was observed.

Methane is acknowledged as a loss of energy to the ruminant system (Chamberlain and Wilkinson, 1996). This can be expressed as $\mathrm{CH}_{4}$ energy emitted as a percentage of GEI. The GEI lost as $\mathrm{CH}_{4}$ is typically 6 to $7 \%$ in forage-based diets (Johnson and Johnson, 1995). The results of the current study indicate that cows offered a TMR diet emitted more $\mathrm{CH}_{4}$ energy as a proportion of GEI than did cows offered a grass diet. The reasons for this difference mirror those reasons discussed above for differences in $\mathrm{CH}_{4}$ emitted on a per unit of feed intake basis. Blaxter and Clapperton (1965) found that diet quality influences the amount of $\mathrm{CH}_{4}$ produced in the rumen, such that the higher the quality, the lower the percentage of energy that is lost as $\mathrm{CH}_{4}$. Similarly, Kujawa (1994) and McAllister et al. (1996) showed that feeds of high quality and with highly digestible fiber gave rise to less $\mathrm{CH}_{4}$ losses as a percentage of GEI. Robertson and Waghorn (2002) found that dairy cows grazing spring grass emitted $4.9 \%$ of GEI and cows offered TMR produced $5.0 \%$ of GEI as $\mathrm{CH}_{4}$. These values are lower than the values in the current study. This is due to the fact that the cows in the Robertson and Waghorn (2002) study produced similar $\mathrm{CH}_{4}$ per unit of intake from a higher DMI, and thus, higher GEI.

Beauchemin et al. (2008) concluded that $\mathrm{CH}_{4}$ emissions should also be expressed on the basis of animal product, as it is possible for an increase in $\mathrm{CH}_{4}$ emissions to be accompanied by a concomitant improvement in animal productivity (e.g., as a result of a greater extent of ruminal forage fermentation). In the current study, the grass-fed group produced less $\mathrm{CH}_{4}$ per $\mathrm{kg}$ of FP than did the TMR group, despite the fact that the TMR group produced more FP. Thus, the extra production of FP from the TMR diet was not large enough to offset the associated higher $\mathrm{CH}_{4}$ emission.
An effect of period on $\mathrm{CH}_{4}$ production was observed. As discussed above, DMI increased from P1 to P2 and, as DMI is the main driver of enteric $\mathrm{CH}_{4}$ emissions (Hegarty et al., 2007), an increase in $\mathrm{CH}_{4}$ emissions per cow per day in $\mathrm{P} 2$ resulted. The change in production performance parameters in P2 due to the later stage of lactation and the concomitant increase in DMI and $\mathrm{CH}_{4}$ production resulted in an increase in $\mathrm{CH}_{4}$ emissions per $\mathrm{kg}$ of $\mathrm{FP}$ and a decrease in $\mathrm{CH}_{4}$ emissions per $\mathrm{kg}$ of DMI in P2 compared with P1.

\section{CONCLUSIONS}

In this study, spring-calving cows consuming a high quality perennial ryegrass diet in spring produced less enteric $\mathrm{CH}_{4}$ per cow, per unit of DMI, and per unit of FP yield than did cows offered a standard TMR diet. The TMR diet used in the current study gave rise to higher milk yield and FP yield due to higher DMI, but this increase was not large enough to offset the substantially greater quantity of enteric $\mathrm{CH}_{4}$ produced. The mechanisms, such as rumen function, passage rate, and digestibility, by which these results were achieved, should be explored further. This study demonstrated that, by offering spring-calving cows in early lactation high quality grass, milk with low enteric $\mathrm{CH}_{4}$ emissions can be produced.

\section{ACKNOWLEDGMENTS}

This work was funded by the Irish Department of Agriculture, Fisheries, and Food Research Stimulus Fund (RSF-07-517). The authors acknowledge the assistance of J. J. Murphy and J. Patton in experimental design, and of M. Feeney, F. Flynn, J. P. Murphy, F. Coughlan, G. Hanrahan, F. Kearney, N. Galvin, and all the farm staff for their care of the experimental animals, assistance with measurements taken during the study, and laboratory analysis (Teagasc, Moorepark, Ireland). We also thank Kenton Hart (UCD, Dublin, Ireland) for his assistance with development of the ERUCT method at Moorepark.

\section{REFERENCES}

Allen, M. S. 1997. Relationship between fermentation acid production in the rumen and the requirement for physically effective fiber. J. Dairy Sci. 80:1447-1462.

Bargo, F., L. D. Muller, J. E. Delahoy, and T. W. Cassidy. 2002. Performance of high producing dairy cows with three different feeding systems combining pasture and total mixed rations. J. Dairy Sci. 85:2948-2963.

Beauchemin, K. A., M. Kreuzer, F. O'Mara, and T. A. McAllister. 2008. Nutritional management for enteric methane abatement: A review. Aust. J. Exp. Agric. 48:21-27.

Blaxter, K. L., and J. L. Clapperton. 1965. Prediction of the amount of methane produced by ruminants. Br. J. Nutr. 19:511-522. 
Boadi, D., C. Benchaar, J. Chiquette, and D. Massé. 2004. Mitigation strategies to reduce enteric methane emissions from dairy cows: Update review. Can. J. Anim. Sci. 84:319-335.

Buddle, B. M., M. Denis, G. T. Attwood, E. Altermann, P. H. Janssen, R. S. Ronimus, C. S. Pinares-Patiño, S. Muetzel, and D. Neil Wedlock. 2010. Strategies to reduce methane emissions from farmed ruminants grazing on pasture. Vet. J. doi:10.1016/j. tvjl.2010.02.019.

Chamberlain, A. T., and J. M. Wilkinson. 1996. Feeding the Dairy Cow. Chalcombe Publications, Lincoln, UK.

Cone, J. W., and A. H. van Gelder. 1999. Influence of protein fermentation on gas production profiles. Anim. Feed Sci. Technol. $76: 251-264$.

Connolly, J., J. A. Finn, A. D. Black, L. Kirwan, C. Brophy, and A. Lüscher. 2009. Effects of multi-species swards on dry matter production and the incidence of unsown species at three Irish sites. Isr. J. Agric. Res. 48:243-260.

CSO (Central Statistics Office). 2007. Census 2006: Volume 1-Population Classified by Area. Central Statistics Office, Dublin, Ireland.

CSO (Central Statistics Office). 2009. Livestock survey: December 2008. Central Statistics Office, Dublin, Ireland.

CSO (Central Statistics Office). 2010. Agriculture milk production. Intake of cows milk by creameries and pasteurisers by month, domestic or import source and statistic. Central Statistics Office, Dublin, Ireland. Accessed Aug. 9, 2010. http://www.cso.ie/px/.

Curran, J., L. Delaby, E. Kennedy, J. P. Murphy, T. M. Boland, and M. O'Donovan. 2010. Sward characteristics, grass dry matter intake and milk production performance are affected by pre-grazing herbage mass and pasture allowance. Livest. Sci. 127:144-154.

DAFF. 2010. Food harvest. A vision of Irish agri-food and fisheries 2020. Department of Agriculture, Fisheries and Food, Dublin, Ireland.

Demeyer, D., and C. Van Nevel. 1979. Protein fermentation and growth by rumen microbes. Ann. Rech. Vet. 10:277-279.

Dillon, P. 1993. The use of n-alkanes as markers to determine intake, botanical composition of available or consumed herbage in studies of digesta kinetics with dairy cows. PhD Thesis. National University of Ireland, Dublin, Ireland.

Dillon, P., S. Crosse, G. Stakelum, and F. Flynn. 1995. The effect of calving date and stocking rate on the performance of springcalving dairy cows. Grass Forage Sci. 50:286-299.

Dillon, P., and G. Stakelum. 1989. Herbage and dosed alkanes as a grass management technique for dairy cows. Ir. J. Agric. Res. 28:104. (Abstr.)

EC (European Commission). 2009. Health Check of the CAP: Current situation, Commission proposal and Council outcome. Accessed Aug. 5, 2010. http://ec.europa.eu/agriculture/healthcheck/ index_en.htm.

EEA (European Environment Agency). 2009. Annual European Community greenhouse gas inventory 1990-2007 and inventory report 2009 submission to the UNFCCC Secretariat. European Environment Agency, Copenhagen, Denmark.

Fitzgerald, J. J., and J. J. Murphy. 1999. A comparison of low starch maize silage and grass silage and the effect of concentrate supplementation of the forages or inclusion of maize grain with the maize silage on milk production by dairy cows. Livest. Prod. Sci. $57: 95-111$.

Fontaneli, R. S., L. E. Sollenberger, R. C. Littell, and C. R. Staples. 2005. Performance of lactating dairy cows managed on pasturebased or in freestall barn-feeding systems. J. Dairy Sci. 88:12641276.

Grainger, C., M. J. Auldist, G. O'Brien, K. L. Macmillan, and C. Culley. 2009. Effect of type of diet and energy intake on milk production of Holstein-Friesian cows with extended lactations. J. Dairy Sci. 92:1479-1492.

Hegarty, R. S., J. P. Goopy, R. M. Herd, and B. McCorkell. 2007. Cattle selected for lower residual feed intake have reduced daily methane production. J. Anim. Sci. 85:1479-1486.
Holden, L. A., L. D. Muller, and S. L. Fales. 1994. Estimation of intake in high producing Holstein cows grazing grass pasture. J. Dairy Sci. $77: 2332-2340$.

Ingvartsen, K. L., and J. B. Andersen. 2000. Integration of metabolism and intake regulation: A review focusing on periparturient animals. J. Dairy Sci. 83:1573-1597.

Jenkins, T. C., and M. A. McGuire. 2006. Major advances in nutrition: Impact on milk composition. J. Dairy Sci. 89:1302-1310.

Johnson, D. E., T. M. Hill, G. M. Ward, K. A. Johnson, M. E. Branine, B. R. Carmean, and D. W. Lodman. 1993. Principle factors varying methane emissions from ruminants and other animals. Pages 199-299 in Atmospheric Methane: Sources, Sinks, and Role in Global Change. Vol. 13. M. A. K. Khalil, ed. Springer Verlag, Berlin and Heidelberg, Germany.

Johnson, K. A., and D. E. Johnson. 1995. Methane emissions from cattle. J. Anim. Sci. 73:2483-2492.

Johnson, K. A., H. H. Westberg, J. J. Michal, and M. W. Cossalman. 2007. The SF6 tracer technique: Methane measurement from ruminants. Page 33 in Measuring Methane Production from Ruminants. H. P. S. Makkar and P. E. Vercoe, ed. Springer, the Netherlands.

Kennedy, E., M. O'Donovan, L. Delaby, and F. P. O'Mara. 2008. Effect of herbage allowance and concentrate supplementation on dry matter intake, milk production and energy balance of early lactating dairy cows. Livest. Sci. 117:275-286.

Kennedy, E., M. O'Donovan, F. P. O'Mara, J. P. Murphy, and L. Delaby. 2007. The effect of early-lactation feeding strategy on the lactation performance of spring-calving dairy cows. J. Dairy Sci. 90:3060-3070

Kertz, A. F., L. F. Reutzel, and G. M. Thomson. 1991. Dry matter intake from parturition to midlactation. J. Dairy Sci. 74:22902295.

Kolver, E. S., and L. D. Muller. 1998. Performance and nutrient intake of high producing Holstein cows consuming pasture or a total mixed ration. J. Dairy Sci. 81:1403-1411.

Kolver, E. S., A. R. Napper, P. J. A. Copeman, and L. D. Muller 2000. A comparison of New Zealand and overseas Holstein Friesian heifers. Proc. N.Z. Soc. Anim. Prod. 60:265-269.

Krause, K. M., and G. R. Oetzel. 2006. Understanding and preventing subacute ruminal acidosis in dairy herds: A review. Anim. Feed Sci. Technol. 126:215-236.

Kujawa, M. A. 1994. Energy partitioning in steers fed cottonseed hulls and beet pulp. PhD Dissertation. Colorado State University, Fort Collins.

Lewis, E., F. Coughlan, C. Wims, and M. A. O'Donovan. 2010. The effect of grazing different pasture herbage masses on rumen $\mathrm{pH}$ in lactating dairy cows. Page 293 in Proc. Br. Soc. Anim. Sci., Belfast, Northern Ireland. British Society of Animal Science, Midlothian, UK.

Linzell, J. L., and M. Peaker. 1971. Mechanism of milk secretion. Physiol. Rev. 51:564-597.

Lowman, B. G., N. Scott, and S. Somerville. 1976. Condition scoring of cattle. Rev. ed. East of Scotland College of Agric., Bull. No. 6. The Edinburgh School of Agriculture, Edinburgh, UK.

Martin, C., D. P. Morgavi, and M. Doreau. 2010. Methane mitigation in ruminants: From microbe to the farm scale. Animal 4:351365.

Mayes, R. W., C. S. Lamb, and P. M. Colgrove. 1986. The use of dosed and herbage n-alkanes as markers for the determination of herbage intake. J. Agric. Sci. 107:70. (Abstr.)

McAllister, T. A., K.-J. Cheng, E. K. Okine, and G. W. Mathison 1996. Dietary, environmental and microbiological aspects of methane production in ruminants. Can. J. Anim. Sci. 76:231-243.

McNaughton, L. R., D. P. Berry, H. Clark, C. Pinares-Patino, S. Harcourt, and R. J. Spelman. 2005. Factors affecting methane production in Friesian $\times$ Jersey dairy cattle. Proc. N.Z. Soc. Anim. Prod. 65:352-355.

Moe, P. W., and H. F. Tyrrell. 1980. Methane production in dairy cattle. Page 59 in Energy metabolism. Proc. 8th Symp. Energy Metab. Butterworths, London, UK. 
Morgan, D. J., G. Stakelum, and J. Dwyer. 1989. Modified neutral detergent cellulase digestibility procedure for use with the 'Fibertec' system. Ir. J. Agric. Res. 28:91-92.

Moss, A. R., J. P. Jouany, and J. Newbold. 2000. Methane production by ruminants: Its contribution to global warming. Ann. Zootech. 49:231-253.

Murphy, J. J., S. Kavanagh, J. Patton, and J. Maher. 2008. Factors affecting mid season milk protein content. Pages $80-85$ in Is Dairy Farming the Solution, Teagasc National Dairy Conference 2008. Teagasc, Ireland

NMA (National Milk Agency). 2009. Milk. National Milk Agency annual report and accounts 2009. Dublin, Ireland.

NRC (National Research Council). 2001. Nutrient Requirements of Dairy Cattle. 7th Rev. Ed. National Academy Press, Washington, DC.

O'Donovan, M. 2000. The relationship between the performance of dairy cows and grassland management on intensive dairy farms in Ireland. PhD Thesis. University College Dublin, Dublin, Ireland.

O'Grady, L., M. L. Doherty, and F. J. Mulligan. 2008. Subacute ruminal acidosis (SARA) in grazing Irish dairy cows. Vet. J. 176:4449.

O'Mara, F. 1996. A net energy system for cattle and sheep. Department of Animal Science and Production, University College Dublin. Ireland.

Patton, J., G. Olmos, and J. J. Murphy. 2008. Comparison of total mixed ration and pasture feeding systems for early lactation dairy cows. Page 30 in Proc. Agric. Res. Forum 2008. Teagasc, Tullamore, Ireland.

Pinares-Patiño, C. S., G. C. Waghorn, A. Machmüller, B. Vlaming, G. Molano, A. Cavanagh, and H. Clark. 2007. Methane emissions and digestive physiology of non-lactating dairy cows fed pasture forage. Can. J. Anim. Sci. 87:601-613.

Robertson, L. J., and G. C. Waghorn. 2002. Dairy industry perspectives on methane emissions and production from cattle fed pasture or total mixed rations in New Zealand. Proc. N.Z. Soc. Anim. Prod. 62:213-218.

Russell, J. B. 1998. The importance of $\mathrm{pH}$ in the regulation of ruminal acetate to propionate ratio and methane production in vitro. J. Dairy Sci. 81:3222-3230.

SAS Institute. 2005. SAS User's Guide: Statistics. SAS Inst., Inc. Cary, NC.

Sauvant, D., J.-M. Perez, and G. Tran. 2004. Molasses, sugarcane. Pages 238-239 in Tables of Composition and Nutritional Value of Feed Materials: Pigs, Poultry, Cattle, Sheep, Goats, Rabbits, Horses, Fish. D. Sauvant, J.-M. Perez, and G. Tran, ed. Wageningen Academic Publishers, Wageningen, the Netherlands.

Smith, P., D. Martino, Z. Cai, D. Gwary, H. Janzen, P. Kumar, B. McCarl, S. Ogle, F. O'Mara, C. Rice, B. Scholes, O. Sirotenko, M. Howden, T. McAllister, G. Pan, V. Romanenkov, U. Schneider, S. Towprayoon, M. Wattenbach, and J. Smith. 2008. Greenhouse gas mitigation in agriculture. Philos. Trans. R. Soc. Lond. B Biol. Sci. 363:789-813.

Sweeney, R. A. 1989. Generic combustion method for determination of crude protein in feeds: Collaborative study. J. Assoc. Off. Anal. Chem. 72:770-774.

Tas, B. M., H. Z. Taweel, H. J. Smit, A. Elgersma, J. Dijkstra, and S. Tamminga. 2005. Effects of perennial ryegrass cultivars on intake, digestibility, and milk yield in dairy cows. J. Dairy Sci. 88:3240-3248

Tucker, W. B., B. J. Rude, and S. Wittayakun. 2001. Case Study: Performance and economics of dairy cows fed a corn silage-based total mixed ration or grazing annual ryegrass during mid to late lactation. Prof. Anim. Sci. 17:195-201.

Tyrrell, H. F., and J. T. Reid. 1965. Prediction of the energy value of cow's milk. J. Dairy Sci. 48:1215-1223.

UNFCCC (United Nations Framework Convention on Climate Change). 1997. Kyoto Protocol to the United Nations Framework convention on Climate Change. Kyoto, Japan.

Van Kessel, J. A. S., and J. B. Russell. 1996. The effect of pH on ruminal methanogenesis. FEMS Microbiol. Ecol. 20:205-210.

Van Soest, P. J., J. B. Robertson, and B. A. Lewis. 1991. Methods for dietary fiber, neutral detergent fiber, and nonstarch polysaccharides in relation to animal nutrition. J. Dairy Sci. 74:3583-3597.

Van Vuuren, A. M., F. Krol-Kramer, R. A. Van der Lee, and H. Corbijn. 1992. Protein digestion and intestinal amino acids in dairy cows fed fresh Lolium perenne with different nitrogen contents. J. Dairy Sci. 75:2215-2225.

Washburn, S. P., S. L. White, J. T. Green Jr., and G. A. Benson. 2002. Reproduction, mastitis, and body condition of seasonally calved Holstein and Jersey cows in confinement or pasture systems. J. Dairy Sci. 85:105-111.

White, S. L., G. A. Benson, S. P. Washburn, and J. T. Green Jr.. 2002. Milk production and economic measures in confinement or pasture systems using seasonally calved Holstein and Jersey cows. J. Dairy Sci. 85:95-104. 